\title{
Isolation and characterization of twenty microsatellite loci for the ballan wrasse, Labrus bergylta
}

\author{
María Quintela • Elin Annie Danielsen • \\ Terje Svåsand · Halvor Knutsen • \\ Anne Berit Skiftesvik • Kevin A. Glover
}

Received: 23 December 2013/Accepted: 25 December 2013/Published online: 3 January 2014

(C) The Author(s) 2014. This article is published with open access at Springerlink.com

\begin{abstract}
We developed 20 nuclear microsatellite DNA markers from tri- and tetra-nucleotide enriched libraries in the ballan wrasse. In our dataset $(\mathrm{N}=241)$, the detected number of alleles per locus ranged from 2 to 12 , and the observed and expected heterozygosity varied from 0.251 to 0.778 and from 0.286 to 0.804 , respectively. Cross amplification with the goldsinny wrasse resulted in two usable loci whereas the corkwing wrasse amplified in one locus. The ballan wrasse is an important resource for aquaculture as it delouses farmed salmon efficiently and removes organic matter from farming facilities. In order to obtain individuals for this industry, the wrasse are translocated along the Norwegian coastline, in spite of no knowledge of the population structure. This paper enables such studies, which might be important for the long term management of the species.
\end{abstract}

Keywords Labrus bergylta $\cdot$ Ballan wrasse microsatellites $\cdot$ Salmon delouser

María Quintela and Elin Annie Danielsen have equally contributed.

M. Quintela · E. A. Danielsen · T. Svåsand · H. Knutsen ·

K. A. Glover $(\bowtie)$

Institute of Marine Research, 5817 Bergen, Norway

e-mail: kevin.glover@imr.no

M. Quintela

e-mail: maria.quintela.sanchez@imr.no

H. Knutsen

Department of Biology, Centre for Ecological and Evolutionary Synthesis (CEES), University of Oslo, PO Box 1066, Blindern, 0316 Oslo, Norway

H. Knutsen

University of Agder, 4604 Kristiansand, Norway

A. B. Skiftesvik

Austevoll Research Station, 5392 Storebø, Norway
The ballan wrasse, Labrus bergylta (Ascanius 1767) is the biggest of the labrids (Parenti and Randall 2000) in Scandinavian waters. This species is exploited commercially as biocontrol in the aquaculture industry, removing lice and organic matter from the sides of cages and nets, thus reducing the environmental impact of salmon farming. It is also popular as food fish and as catch-and-release target for sport fishermen.

Genomic DNA was extracted from fin tissue of 15 individuals using the Qiagen DNeasy Blood \& Tissue Kit following manufacturer's instructions. Commercial company Genetic Identification Services (GIS Inc., Chatsworth, USA; http://genetic-id-services.com) was requested to develop and screen two multiplexed libraries enriched for four tetranucleotide (TAGA), (CATC), (AAAC), (CAGA) and four trinucleotide motifs (ATC), (AAC), (AGT), (ACC) following their proprietary protocol (Meredith and May 2002). A total of 368 clones were sequenced and 92 microsatellites were found. PCR primers for 76 microsatellite-containing sequences were designed using DesignerPCR v.1.03 (Research Genetics, Inc.). Some 43 primer pairs successfully amplified and 22 were polymorphic on a sample of eight individuals.

We assessed the variability of those polymorphic loci in 241 specimens collected from five sites in Norway. Six multiplexed PCR reactions were performed in final volume of $10 \mu \mathrm{l}$ containing $50 \mathrm{ng}$ DNA template, $1 \times$ buffer, $2 \mathrm{mM} \mathrm{MgCl}_{2}, 1.25 \mathrm{mM}$ dNTPs, $0.06-0.12 \mu \mathrm{M}$ of each primer and $1 \mathrm{U}$ GoTaq polymerase (Table 1). PCR profiles included an initial 4 min denaturation at $94{ }^{\circ} \mathrm{C}$ followed by 24 cycles of $50 \mathrm{~s}$ at $94{ }^{\circ} \mathrm{C}, 90 \mathrm{~s}$ at an annealing temperature of $56{ }^{\circ} \mathrm{C}, 1 \mathrm{~min}$ of extension at $72{ }^{\circ} \mathrm{C}$ and a final extension of $72{ }^{\circ} \mathrm{C}$ for $10 \mathrm{~min}$. Forward primers were labelled with fluorescent dyes and PCR products were electrophoresed on an ABI Prism 377 Genetic Analyzer 


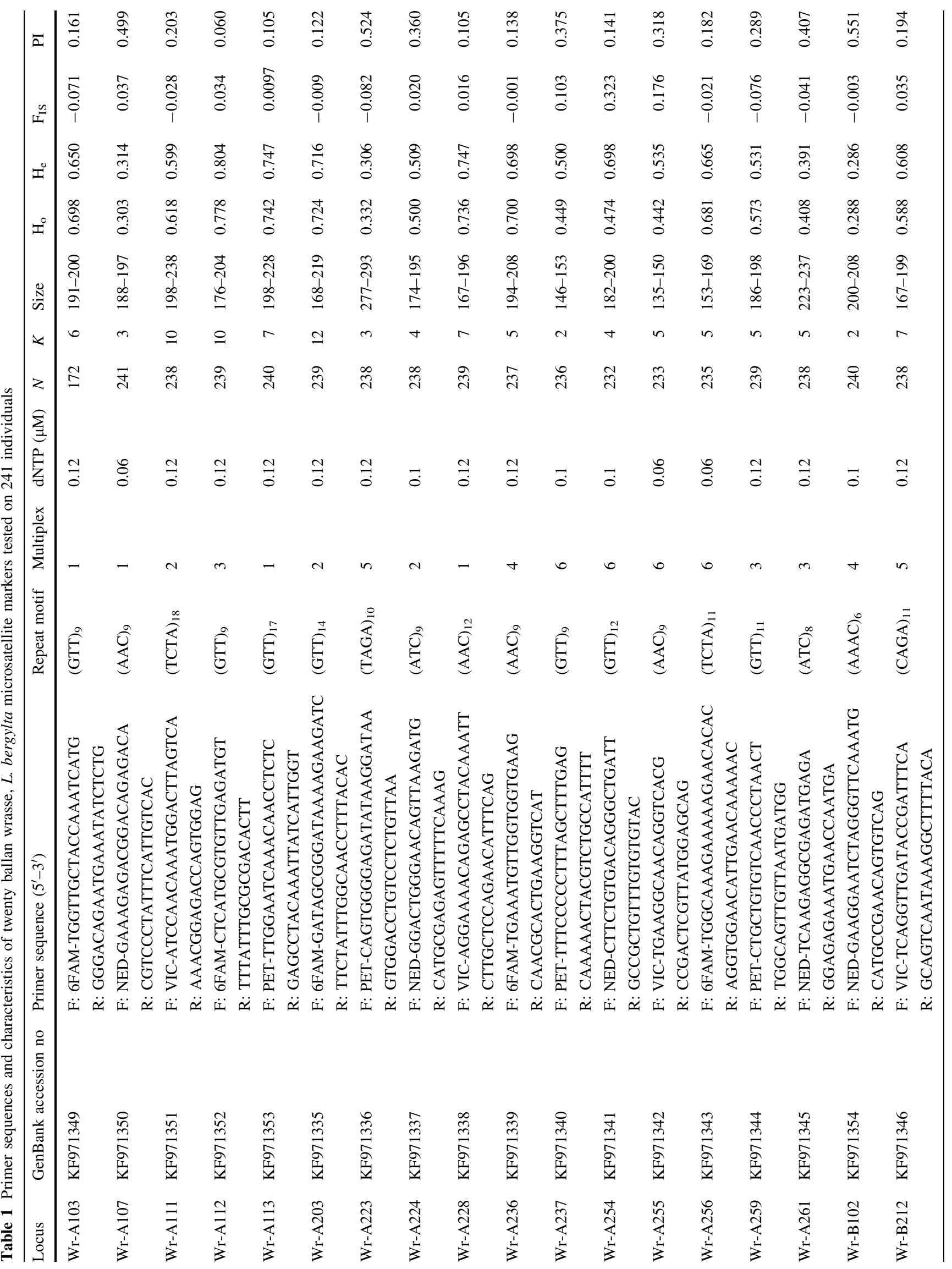


(Applied Biosystems). The 500LIZ size standard (Applied Biosystems) was used to accurately determine the size of the fragments and allelic variation. Conditions and characteristics of the loci are provided in Table 1.

Fragments were analyzed with the software GeneMapper v5 (Applied Biosystems), and Micro-Checker with 1,000 randomizations (Van Oosterhout et al. 2004) was used to evaluate presence of null alleles, stutter bands and large allele dropout. The number of alleles per locus ( $\mathrm{k}$ ), the observed and expected heterozygosity $\left(\mathrm{H}_{\mathrm{o}}\right.$ and $\left.\mathrm{H}_{\mathrm{e}}\right)$, the inbreeding coefficient $\left(\mathrm{F}_{\mathrm{IS}}\right)$, the probability of identity (PI) and Hardy-Weinberg equilibrium tests (HWE) for each locus were calculated using GenAlEx 6.5 (Peakall and Smouse 2006). Linkage disequilibrium (LD) between pairs of loci was tested using GENEPOP on the web (Rousset 2008).

Twenty of the primers managed to amplify successfully in multiplex and produced an average of six alleles per locus. The duplicated genotyping of the 241 individuals revealed no inconsistencies in 12 of the loci whereas in the eight remaining ones, the percentage of mismatches ranged between 0.21 and $0.65 \%$. MicroChecker suggested homozygote excess in loci Wr-A254, $\mathrm{Wr}-\mathrm{A} 255$ and $\mathrm{Wr}-215$. The averaged observed heterozygosity over all loci $\left(\mathrm{H}_{\mathrm{o}}\right)$ and the level of expected heterozygosity $\left(\mathrm{H}_{\mathrm{e}}\right)$ were 0.552 and 0.557 respectively. After FDR correction for multiple comparisons, three loci showed significant deviations from expectations under HWE and one case of no LD was detected among the 190 paired loci comparisons. Cross-species amplification was tested on the goldsinny wrasse, Ctenolabrus rupestris, which amplified at loci Wr-A237 and Wr-B102; and on the corkwing wrasse, Symphodus melops that amplified at Wr-B102.

Acknowledgments Funding was provided by the Norwegian Ministry of Fisheries and Coastal Affairs. We are grateful to Anne Grete Sørvik Eide, Bjørghild Breistein Seliussen and Geir Dahle for their valuable assistance in the laboratory.

Open Access This article is distributed under the terms of the Creative Commons Attribution License which permits any use, distribution, and reproduction in any medium, provided the original author(s) and the source are credited.

\section{References}

Meredith EP, May B (2002) Microsatellite loci in the Lahontan tui chub, Gila bicolor obesa, and their utilization in other chub species. Mol Ecol Notes 2:156-158

Parenti P, Randall JE (2000) An annotated checklist of the species of the labroid fish families Labridae and Scaridae. Ichthyol Bull 68:1-97

Peakall R, Smouse PE (2006) GenAlEx 6: genetic analysis in excel. Population genetic software for teaching and research. Mol Ecol Notes 6:288-295 
Rousset F (2008) GENEPOP'007: a complete re-implementation of the genepop software for Windows and Linux. Mol Ecol Resour $8: 103-106$
Van Oosterhout C, Hutchinson WF, Wills DPM, Shipley P (2004) MICRO-CHECKER: software for identifying and correcting genotyping errors in microsatellite data. Mol Ecol Notes 4:535-538 